\title{
Hegemony and Ideology in Novel Bidadari Bermata Bening by Habiburrahman el Shirazy (Gramsci Hegemony Study)
}

\author{
Fajrul Falah* \\ Indonesian literature, Faculty of Humanities, Diponegoro University, Indonesia
}

\begin{abstract}
The purpose of this study is to reveal the hegemony and ideology contained in the novel Bidadari Bermata Bening $(B B B)$ by Habiburrahman el Shirazy. Research with the novel's object and Gramsci's hegemony approach, based on searches in online journals not yet found. The research method used is descriptive analytic. This research data consists of words, phrases, sentences, texts, and discourses included in novel $B B B$. The results showed that the central character Ayna was built to have a positive character such as being obedient, religious, beautiful, and smart. The religious ideology embraced by Ayna, able to bind and make himself face various tests of life, like divorced and then remarried. The hegemony process between Ayna (student) and Gus Afif (teacher) also went well, because the patron-client culture in the pesantren environment is still strong.
\end{abstract}

Keywords: Environment; pesantren; religious; hegemony; and ideology.

\section{Introduction}

Text contained in a fiction (novel) is indicated full of meaning, both explicit or implicit. This novel is made by a writer or author with a role or language medium. The language in the novel is in the form of words, phrases, sentences, and discourse. The language in the novel, although considered fiction (not reality) and the dominant aesthetic element, is not neutral. Novels that have been made are indicated to have close relevance to the author's ideology and background. The writer's work (novel) is indicated to be influenced by, inter alia, the environment, education, profession, and life outlook of the author. If so, then a novel has a message and can be interpreted; whether he as a medium to invite good or otherwise, badness. Does it (the novel) affect or inspire the reader in a positive direction, or does it actually lead to negative things. Is the language in the novel interpreted as God's verses (inviting goodness) or vice versa as Satan's verses (full of badness)[1].

The novel that is indicated to have meaning and full of ideological messages is Bidadari Bermata Bening by Habiburrahman el Shirazy. This novel Bidadari Bermata Bening (Hereinafter abbreviated $B B B$ ) is one of the many works of Habiburahman el Shirazy. The

\footnotetext{
* Corresponding author: fajrul.falah@live.undip.ac.id
} 
creation of Habiburahman el Shirazy are generally set in pesantren, with the theme of religion, education and even marriage. Other Habiburahman's works, including Ayat-Ayat Cinta, Bumi Cinta, Di Atas Sajadah Cinta, Dalam Mihrab Cinta, and Pudarnya Pesona Cleopatra. The novel Bidadari Bermata Bening is indicated to be similar to the real life of the pesantren world [2]. Why does every character in the novel have respectful and obedient behavior towards people who have positions? Why do the characters in the novel have many positive characters or attributes such as being obedient, diligent in worship, handsome, beautiful, smart, and patient.

Why also in the novel there are figures who have power and there are figures who are mastered. Why the characters controlled can accept it well or voluntarily. These problems and questions are interesting to solve and answer. In summary, the purpose of this study is to answer the question of how the hegemony and ideology contained in the $B B B$ by Habiburahman el Shirazy. The research approach used is Gramsci hegemony. The results of the research are expected to be used as literary lectures and contribute to the development of literary research.

Based on searches on google and in online journals found one study related to novel $B B B$, namely Yanda and Ramadhanti [3]. The novel is examined using multimodal discourse analysis with a semiotic approach. Another study by Falah examined the novel by Habiburahman with the Gramsci hegemony approach, but used a novel Ketika Cinta Bertasbih [1]. The results showed the main characters Khairul Azzam and Anna Althafunnisa could live in harmony and happiness because they embraced and carried out their religious ideology. Another study (Falah) examines novel Ayat-Ayat Cinta by Habiburahman with Gramsci's hegemony approach. The results showed Fahri's figure was able to do religious ideology hegemony well against other figures. These studies use each approach [4]. The author focuses his research on novel $B B B$ to reveal the forms of hegemony and ideology.

Hegemony is a form of leadership in a voluntary way, not coercion. The power of hegemony runs ideologically and politically [5 and 6]. Ideology in the novel is interpreted as a form of ideas, ideas, beliefs of certain figures. Hegemony and ideology are carried out by way of being produced (maker), distribution (distributor), and consumption (user) [7]. Hegemony and ideology are able to bind and dominate certain social classes voluntarily and peacefully [8 and 9]. The hegemony and ideology in the $B B B$ novel are interpreted as a form of power and acceptance of certain social classes.

\section{Method}

This research uses the material object of the Bidadari Bermata Bening novel by Habiburrahman el Shirazy, published by Republika in 2017. The formal objects of this research are hegemony and ideology. This research enters the realm of literary sociology, with the perspective of Gramsci's hegemony. This research is classified as library research. The work steps in this library research include (1) data collection, (2) data analysis, and (3) presentation of results. Data collection is done by selecting novel Bidadari Bermata Bening research objects. The novel is then read over and over again carefully, marked with words, phrases, and sentences related to hegemony and ideology. Data analysis was performed by interpreting research data in accordance with the approach used, namely Gramsci hegemony.

\section{Result and Discussion}

Analysis of hegemony and ideology, so that it is more clearly preceded by a synopsis or a brief summary of the $B B B$ novel. The characters and characters in the novel are presented so that their roles and positions are clear. There is a dominant figure (dominate) and there is also 
a weak figure (controlled). The figures and their characters in the $B B B$ novel that is, Aynul Mardhiyah (Ayna), Gus Afiffudin, Kiai Sobron, Mrs Fauziyah, Yoyok, Kusmono, Neneng, Pakde Darsun, dan Rosidah. Ayna is the main character who has a patient character, beautiful, tough, obedient, and smart. Guz Afif (kind, patient, religious), Kiai Sobron dan Mrs Fauziyah (obedient, patient), Yoyok (ambitious, greedy), Kusmono (ambitious, greedy), Neneng (arrogant, rude), Pakde Darsun (ambitious, apathetic), and Zulfa (kind, helper). The role and position of the character can change depending on context. The following is a table of the positions of the characters in the $B B B$ novel.

Table 1. Character Position

\begin{tabular}{|l|l|}
\hline Strengh (Dominate) & Weakness (controlled) \\
\hline Gus Afiffudin & Aynul Mardhiyah \\
\hline Kiai Sobron & Kusmono \\
\hline Ibu Fauziyah & Neneng \\
\hline Yoyok & Pakde Darsun \\
\hline Ibu Rosidah & Zulfa \\
\hline
\end{tabular}

\section{Religious Ideology}

The religious ideology in the $B B B$ novel is so prominent, especially attached to the main characters such as Ayna, Gus Afif, Kiai Sobron and Mrs. Fauziyah. Religious values (Islam) such as obedience and prayer, can be found among them when Ayna Reading sholawat. Ayna read the sholawat while riding a motorcycle to be saved [2,p6]. In the ideology embraced by Ayna, sholawat is believed to have many virtues, for example, a form of obedience to God, salvation, and calmness. Ayna is well aware that in every activity there is a role God and needs to be remembered. In the ideology embraced by Ayna, views also emerged "who often remembers his God (Allah), so God will remember him". Besides that, the words of the sholawat show the low heart shape of Ayna. Even though Ayna was able to drive a motorcycle without prayer, he still doesn't forget to pray. Ayna's religiosity eventually led to the kiai Sobron and and Mrs. Fauziyah wants to make her daughter-in-law. Kiai Sobron hopes that Ayna marries Guz Afif.

\section{Client Patron Hegemony}

The relationship between the santri and the kiai is patron-client. Santri obeys and respects the kiai. Relatively different from the relationship of students with teachers in formal schools. The kiai in the pesantren world have strong authority and charisma. Some santri (women) even hoped to be the kiai's daughter -in-law or wife. The position of the kiai, who is strong and above the santri, is a bargaining value for choosing santri to be his wife. It also appears in the $B B B$ novel, when kiai Sobron asked Ayna to marry his son, Guz Afif. After divorcing Yoyok's first husband, Ayna met with Gus Afif. Kiai Sobron and Mrs. Fauziyah asked Ayna to be Gus Afif's wife, Ayna gladly accepted it. In this context, the position of the kiai Sobron, Mrs. Fauziyah became dominant (superior), while the position of Ayna (inferior) accepts voluntarily. Ayna, who was originally a santri and servant (khadim) at the pesantren owned by Kiai Sobron, now a part of his family. The dream that when a santri was fought for, finally came true. 


\section{Economic Hegemony and Status}

Individuals who have economic capital and are supported by prestige, able to control other people. This was proven when Ayna first married Yoyok. Yoyok is a child of Kusmono legislative member (DPRD in Purwodadi) rich and famous. Ayna will initially be married to Gus Afif, son of Kiai Sobron, but uncle Darsono refused. Uncle Darsono more agree Ayna married Yoyok [2,p134]. In this context, those who were dominate and strong were Yoyok, Kusmono, and uncle Darsono. With the power of money and position, he was able to conquer Ayna and realize his will. Meanwhile, those who are hegemony (inferior) are Kiai Sobron, Mrs. Fauziyah, and Gus Afif. They have not been able to get Ayna. Ayna and Gus Afif live their lives and tests with patience. Their patience is sweet, after the two meet and get married.

\section{Conclusion}

The dominant ideology in the $B B B$ novel is religion (Islam). The main figures Ayna and Guz Afif are religious female and male figures. They have obedient, smart, patient, and kind characters. Their ideology and character are the key to passing the life test. The two separated although they finally united (married). The same background of the pesantren makes both live peacefully and happily. In addition, novels that are made cannot be separated from the background of even the author's ideology. Habiburrahman is a figure who lives in a boarding school (pesantren) environment.

\section{References}

1. F. Falah. Nsa. J. 13, 4 pp. 533-542. (2018).

2. H.E. Shirazy. (Bidadari Bermata Bening. Jakarta: Republika, 2017).

3. D.P. Yanda and D. Ramadhanti. Grm. J. 4, 2, pp. 214-226. (2018).

4. F. Falah. Nsa. J. 13, pp. 351- 360. (2018)

5. A. Gramsci. (Selections from Prison Notebook, edited and translated by Quentin Hoare and Geoffray N Smith. London: Lawrenceadn Wishart, 1971).

6. R. Simon. (Gagasan-gagasan Politik Gramsci. Terj. Kamdani dan I. Baihaqi. Yogyakarta: Pustaka Pelajar, 2001).

7. F. Falah. Nsa. J. 12, 2, pp.100-107. (2017).

8. H. Kurniawan. (Sosiologi Sastra: Teori, Metode, dan Aplikasi. Yogyakarta: Graha Ilmu, 2012).

9. Faruk. (Pengantar Sosiologi Sastra dari Strukturalisme Genetik sampai PostModernisme. Yogyakarta: Pustaka Pelajar, 2010). 